\title{
Higher prevalence of multidrug-resistant extended-spectrum $\beta$-lactamases producing Escherichia coli in unorganized pig farms compared to organized pig farms in Mizoram, India
}

\author{
R. Mandakini ${ }^{1}$, P. Roychoudhury ${ }^{1}$ D , P. K. Subudhi ${ }^{1}$, H. Kylla ${ }^{\mathbb{D}}$, I. Samanta ${ }^{\mathbb{D}}$, S. Bandyopadhayay ${ }^{3}$ (D) \\ and T. K. Dutta ${ }^{1}$ (D)
}

1. Department of Veterinary Microbiology, College of Veterinary Sciences and Animal Husbandry, Central Agricultural University, Aizawl, Mizoram, India; 2. Department of Veterinary Microbiology, West Bengal University of Animal and Fishery Sciences, Kolkata, West Bengal, India; 3. ICAR-Eastern Regional Station of IVRI, Kolkata, West Bengal, India. Corresponding author: T. K. Dutta, e-mail: tapandutta@rediffmail.com

Co-authors: RM: mandaraaj@gmail.com, PR: parimal74@rediffmail.com, PKS: subudhipk@gmail.com, HK: hosternelson@yahoo.com, IS: isamanta76@gmail.com, SB: samiranvet@gmail.com

Received: 03-08-2020, Accepted: 09-11-2020, Published online: 23-12-2020

doi: www.doi.org/10.14202/vetworld.2020.2752-2758 How to cite this article: Mandakini R, Roychoudhury P, Subudhi PK, Kylla H, Samanta I, Bandyopadhayay S, Dutta TK (2020) Higher prevalence of multidrug-resistant extended-spectrum $\beta$-lactamases producing Escherichia coli in unorganized pig farms compared to organized pig farms in Mizoram, India, Veterinary World, 13(12): 2752-2758.

\begin{abstract}
Aim: The present study was conducted to record the prevalence of multidrug-resistant (MDR), extended-spectrum $\beta$-lactamases (ESBLs) producing Escherichia coli from pig population of organized and unorganized farms of Mizoram and to record the presence of ESBLs, non-ESBLs, and integrons.

Materials and Methods: Fecal samples were collected from pigs under organized $(n=40)$ and unorganized $(n=58)$ farms of Mizoram. Samples were processed for isolation and identification of E. coli by conventional techniques, BD Phoenix ${ }^{\mathrm{TM}}$ automated bacterial system, and polymerase chain reaction (PCR) based confirmatory test. All the isolates were subjected to antimicrobial sensitivity test by disk diffusion assay and ESBLs production by double-disk synergy test (DDST). The ESBLs producing isolates were subjected to PCR for determination of ESBLs genes and all the isolates were screened for non-ESBLs genes and integrons by PCR.

Results: A total of 258 E. coli was isolated and identified from organized $(\mathrm{n}=120)$ and unorganized farms $(\mathrm{n}=138)$. Majority of the E. coli isolates exhibited high level of resistance against amoxicillin (Ax) (81.78\%), cefalexin (85.42\%), co-trimoxazole $(50.78 \%)$, sulfafurazole $(69.38 \%)$, tetracycline $(65.89 \%)$, and trimethoprim (TR) $(51.94 \%)$. Statistically highly significant $(\mathrm{p}<0.01)$ variations in resistance among the isolates from organized and unorganized farms were recorded in case of Ax, ampicillin, cephalexin, ciprofloxacin, co-trimoxazole, gentamicin, piperacillin, and TR. By DDST, 65.89\% isolates were recorded as ESBLs producer, of which 82/120 (68.33\%) and 88/138 (63.77\%) were from organized and unorganized farms, respectively. A total of 29/258 (11.24\%) isolates were positive for at least one ESBLs gene. bla ${ }_{T E M}$ was most frequently $(9.69 \%)$ gene, followed by bla $a_{C T X-\mathrm{M}}(5.04 \%)$ and $b l a_{C M Y}(0.78 \%)$. Altogether, $6(5.00 \%), 4(3.33 \%)$, and 2 $(1.67 \%)$ isolates from the organized farms were positive for bla $_{C T X-M}$, $b l a_{T E M}$, and bla ${ }_{C M Y}$ genes, respectively. Similarly, 21 $(15.22 \%)$ and $7(5.07 \%)$ isolates from the unorganized farms were positive for $b l a_{T E M}$ and $b l a_{C T X M}$ genes, respectively. None of them were positive for $b_{l} a_{S H V}$ genes. Altogether $57(22.09 \%), 9(3.49 \%), 66(25.58 \%), 78$ (30.23\%), $21(8.14 \%)$, and 18 (6.98\%) isolates were positive for tetA, tetB, sul1, sul2, aadA, and dfrla genes, respectively. The prevalence of non-ESBLs genes was higher in the E. coli isolates from the unorganized farms than organized farms.
\end{abstract}

Conclusion: MDR and ESBLs producing E. coli are circulating among the pigs and their environment in Mizoram. Pigs under unorganized farms exhibited higher level of resistance against majority of the antimicrobials, including third-generation cephalosporins, which might be an indication of overuse or misuse of antibiotics under the unorganized piggery sectors in Mizoram.

Keywords: Escherichia coli, extended-spectrum $\beta$-lactamases, India, Mizoram, multidrug-resistant, pig.

\section{Introduction}

Escherichia coli is a normal gastrointestinal microflora of the worm-blooded animals, including human beings, which are also capable to develop various clinical conditions under favorable environment.

Copyright: Mandakini, et al. Open Access. This article is distributed under the terms of the Creative Commons Attribution 4.0 International License (http://creativecommons.org/licenses/ by/4.0/), which permits unrestricted use, distribution, and reproduction in any medium, provided you give appropriate credit to the original author(s) and the source, provide a link to the Creative Commons license, and indicate if changes were made. The Creative Commons Public Domain Dedication waiver (http:// creativecommons.org/publicdomain/zero/1.0/) applies to the data made available in this article, unless otherwise stated.
To reduce the morbidity and mortality of the disease conditions associated with bacterial infections, application of antibiotics is common practice since its discovery. However, E. coli is well known to be capable of the development of antimicrobial resistance (AMR) very frequently through accepting and transferring the resistance traits under selection pressure [1]. Development and dissemination of resistance traits from the resistant $E$. coli to other groups of bacteria are multifaceted and are probably evolving constantly. Reports on multidrug-resistant (MDR) bacteria in human [2], animals [3], or environment [4] are well documented throughout the world by various workers. 
Development, maintenance, and dissemination of AMR among the bacteria in human and animals in any particular geographical region are a dynamic process and depend on multiple factors [5]. Excessive use and abuse of antimicrobials are considered to be the most important driving factors, particularly in the developing and underdeveloped countries [6].

Resistance to antimicrobial agents in microorganisms can either be intrinsic or acquired. Intrinsic resistance comprises all of the inherent properties, which are located on the chromosome of a particular species. E. coli naturally produces a chromosomal non-inducible AmpC ß-lactamase expressed at a low level, which is responsible for resistance to penicillin [7]. Other chromosomal resistance mechanisms include low permeability for a specific drug and/ or due to the intrinsic presence of multidrug efflux pumps [8]. Most common type is acquired resistance, in which a strain of an originally susceptible species becomes resistant. Acquired resistance mechanisms involve mutations in genes targeted by the antimicrobial agent or transfer of resistance determinants borne on plasmids, bacteriophages, transposons, and other mobile genetic elements [1].

Among the worldwide array of antibiotics, $\beta$-lactams are the most widely used agents. The most common cause of resistance to $\beta$-lactam antibiotics are the production of $\beta$-lactamases. Over the years, many $\beta$-lactam antibiotics have been developed; however, with each new class of antibiotics, a new $\beta$-lactamase emerged that caused resistance to that class of drug [9]. Extended-spectrum $\beta$-lactamases (ESBLs) are the rapidly evolving group of $\beta$-lactamase enzymes produced by the Gram-negative bacteria, which have the ability to hydrolyze all cephalosporins and aztreonam but are inhibited by clavulanic acid [4]. In addition to the ESBLs production, coresistance against other antimicrobial agents such as sulfa, carbapenems, aminoglycosides, and tetracyclines (TE) are also reported among the E. coli isolates by various workers [10].

In Mizoram, pig farming is the most important backbone of the rural economy. On most occasions, pigs are reared by individual farmers under swill feeding to minimize the input costs. However, few organized farms are also available for large scale production of pork to meet the local demands. So far, no systematic study was conducted to find out the existence of MDR E. coli in the organized and unorganized farming system in Mizoram. Sporadic studies conducted in North Eastern India confirmed the presence of ESBLs $\left(b_{C l a_{C X-M}}\right.$ and $\left.b l a_{S H V}\right)$ through isolation of E. coli from fecal samples of pigs [11]. An ESBL-producing $E$. coli possessing $b l a_{C T X-M}$ and $b l a_{S H V}$ associated with human diarrhea has been reported in India [12]. Puii et al. [4] also reported the prevalence of ESBL producing genes $\left(b l a_{T E M}, b l a_{C T X-M}\right.$ and $\left.b l a_{C M Y}\right)$ in the enteric bacteria of pig population in Northeastern India.

Although few sporadic reports are available, no systematic efforts have been made till date to detect the MDR E. coli in pigs maintained under organized and unorganized farming system of Mizoram and their subsequent characterization. The present study was formulated on isolation, identification, drug resistance properties, and molecular characterization of MDR E. coli strains prevalent in pigs maintained under various farming system.

\section{Materials and Methods}

\section{Ethical approval}

As there were no invasive techniques applied under any of the experiments, including sample collections, ethical approval is not applicable for this study.

\section{Sample collection}

Fresh fecal samples were collected randomly from pigs of Mizoram during the period of September 2012 to May 2014. A total of 98 samples were collected randomly from 40 pigs maintained under organized $(n=4)$ and 58 pigs from unorganized $(n=29)$ farming system irrespective of age, sex, and with or without a history of diarrhea during the study. All the samples were collected using a sterilized absorbent cotton swab. However, for collection of samples from distant locations, sterilized swabs dipped in brain heart infusion broth were used as a transport medium and transported to the laboratory under cold chain $\left(4^{\circ} \mathrm{C}\right)$ for further processing.

\section{Isolation and identification of $E$. coli}

The collected fecal samples were processed for isolation and identification of $E$. coli using standard bacteriological techniques. Five single pure colonies were picked from each inoculated plate for further confirmation. All the isolates were further confirmed by BD Phoenix ${ }^{\mathrm{TM}}$ automated bacterial identification system and $E$. coli species-specific polymerase chain reaction (PCR) targeting the uidA gene. All the isolates were stored as pure culture in semi-solid agar at $4^{\circ} \mathrm{C}$ as well as in Luria Bertani (LB) broth (HiMedia, Mumbai) containing $25 \%$ glycerol (v/v) (Sigma) at $-80^{\circ} \mathrm{C}$ for further use.

\section{Antibiotic susceptibility test and confirmatory test for ESBLs}

Antimicrobial susceptibility test was done on Mueller-Hinton agar (HiMedia, Mumbai) plate as per the recommendation of Clinical Laboratory Standard Institute [13] using the following commercially (HiMedia, Mumbai) available antibiotic disks: Amoxicillin (Ax, $30 \mathrm{mcg}$ ), ampicillin (AMP, $10 \mathrm{mcg}$ ), aztreonam (AZ, $30 \mathrm{mcg})$, cefalexin $(\mathrm{CN}, 30 \mathrm{mcg})$, cefixime (CFM, $30 \mathrm{mcg}$ ), cefotaxime (CTX, $30 \mathrm{mcg}$ ), ceftazidime (CAZ, $30 \mathrm{mcg}$ ), ceftriaxone (CTR, 30 $\mathrm{mcg}$ ), ciprofloxacin (CIP, $5 \mathrm{mcg}$ ), co-trimoxazole (COT, 1.25/23.75 mcg), gentamicin (GEN, $10 \mathrm{mcg}$ ), imipenem (IPM, $10 \mathrm{mcg}$ ), nalidixic acid (NA, $30 \mathrm{mcg}$ ), piperacillin (PI, $100 \mathrm{mcg}$ ), streptomycin (S, $10 \mathrm{mcg}$ ), sulfafurazole/sulfisoxazole (SF, $300 \mathrm{mcg}$ ), TE (TE, 30 $\mathrm{mcg}$ ), and trimethoprim (TR, $30 \mathrm{mcg}$ ) (Table-1). 
Confirmatory test for ESBLs production was carried out using CTX (30 mcg), Ax (30 mcg), and CAZ (30 mcg) alone as well as CTX/clavulanate (30/10 mcg), Ax/clavulanate (30/10 mcg), and CAZ/ clavulanate $(30 / 10 \mathrm{mcg})$ combination as per the recommendation of CLSI [13]. Both the disks were placed at least $25 \mathrm{~mm}$ apart, center to center, on a lawn culture of the test isolate in Mueller-Hinton agar plate and incubated overnight at $37^{\circ} \mathrm{C}$. The difference in zone diameters with and without clavulanic acid was measured. When there was an increase of $\geq 5 \mathrm{~mm}$ in inhibition zone diameter around antimicrobial agent tested in combination with clavulanic acid versus its inhibition diameter zone, when tested alone was confirmed as potent ESBLs producing isolates.

\section{Genotypic detection of antibiotic resistance profile}

The presence of AMR genes was analyzed by PCR using bacterial lysate as a template DNA. Detection of AMR genes were performed for sulfamethoxazole resistant isolates ( $\mathrm{Sul}$ and Sul2), AMP resistance isolates $\left(\right.$ bla $_{T E M}, b l a_{S H \mathcal{V}}, b l a_{C T X-M}$ and $\left.b l a_{C M Y}\right)$, TE resistant isolates (tet $A$, tet $B), \mathrm{S}$ resistant isolates ( $a a d A)$, and TR resistant isolates ( $d f r I a)$ using specific oligonucleotide primers. Details of oligonucleotide primers are depicted in Table-1. PCR conditions were followed as per the method described by Mandakini et al. [14] with suitable modifications. The repeatability of the assay was checked by repeating the PCR 3 times.

\section{Detection of antibiotic resistance integrons}

The MDR isolates were also screened for the presence of class 1 and 2 integrons, namely, intIl and intI2 as well as its gene cassettes $5 \mathrm{CS} / 3 \mathrm{CS}$ and TiB/TiF. PCR amplification was used to detect Class 1 and Class 2 integrase genes (intII and intI2, respectively) using specific primers. The condition used for amplification of the two integrase genes was as follows: Initial denaturation at $94^{\circ} \mathrm{C}$ for $5 \mathrm{~min}, 30$ amplification cycles consisting of $50 \mathrm{~s}$ at $94^{\circ} \mathrm{C}, 50 \mathrm{~s}$ at $60^{\circ} \mathrm{C}$ and $1 \mathrm{~min}$ at $72^{\circ} \mathrm{C}$, and final extension for $6 \mathrm{~min}$. Amplification of variable region of Class 1 and Class 2 integrons was performed using the primers $5^{\prime}-\mathrm{CS} / 3^{\prime}-\mathrm{CS}$ and $\mathrm{Ti}-\mathrm{F} /$ $\mathrm{Ti}-\mathrm{B}$, as per the conditions and procedures described previously by Mandakini et al. [14].

\section{Results}

\section{Isolation of $E$. coli}

A total of $258 \mathrm{E}$. coli was isolated and identified by traditional bacteriological techniques, BD Phoenix automated bacterial system and PCR based confirmation, of which 120 and 138 were from organized and unorganized farms, respectively.

\section{Antibiotic susceptibility of the isolates}

Majority of the E. coli isolates from organized and unorganized farms of Mizoram exhibited high level of resistance against $\mathrm{Ax}(81.78 \%), \mathrm{CN}(85.42 \%)$, co-trixamozole (50.78\%), SF (69.38\%), TE (65.89\%), and TR (51.94\%). IPM was found to be the most sensitive antimicrobials. Among the $E$. coli isolates from organized farms, highest resistance was recorded against CN (96.00\%), followed by AMP (92.50\%), SF $(64.17 \%)$, and TE (61.67\%). Similarly, in case of $E$. coli isolates from unorganized farms maximum resistance was recorded against $\mathrm{CN}(73.91 \%)$ and SF (73.91\%), followed by AMP (72.46\%), TE (69.57\%), and TR (64.49\%). E. coli isolates from organized farms showed higher resistance against Ax, cephalexin, cefixime, and NAs than their unorganized counterparts. On the other hand, E. coli isolates from unorganized farms showed higher resistance

Table-1: Details of the oligonucleotide primers used in the present study.

\begin{tabular}{|c|c|c|c|}
\hline Primer name & Sequence $\left(5^{\prime} \rightarrow 3^{\prime}\right)$ & Expected amplicon size (bp) & Annealing temperature $\left({ }^{\circ} \mathrm{C}\right)$ \\
\hline$b l a_{T E M}$ & $\begin{array}{l}\text { ATAAAATTCTTGAAGACGAAA } \\
\text { GACAGTTACCAATGCTTAATC }\end{array}$ & 1080 & 53 \\
\hline$b l a_{S H V}$ & $\begin{array}{l}\text { CTITCCCATGATGAGCACCT } \\
\text { CGCTGTTATCGCTCATGGTA }\end{array}$ & 206 & 60 \\
\hline bla ${ }_{C T X-M}$ & $\begin{array}{l}\text { CAATGTGCAGCACCAGTAA } \\
\text { CGCGATATCGTTGGTGGTG }\end{array}$ & 540 & 58 \\
\hline bla $_{C M Y}$ & $\begin{array}{l}\text { TGGCCAGAACTGACAGGCAAA } \\
\text { TाTCTCCTGAACGTGGCTGGC }\end{array}$ & 462 & 60 \\
\hline tet $A$ & $\begin{array}{l}\text { GTAATTCTGAGCACTGTCGC } \\
\text { CTGCCTGGACAACATTGCTT }\end{array}$ & 937 & 57 \\
\hline tet $B$ & $\begin{array}{l}\text { TTGGTTAGGGGCAAGTIT } \\
\text { GTAATGGGCCAATAACAC }\end{array}$ & 659 & 57 \\
\hline $\operatorname{aad} A$ & $\begin{array}{l}\text { GCAGCGCAATGACATTCTTG } \\
\text { ATCCTTCGGCGCGATTTTG }\end{array}$ & 282 & 58 \\
\hline DfrIa & $\begin{array}{l}\text { GTGAAACTATCACTAATGG } \\
\text { TTAACCCTITTCCAGATTT }\end{array}$ & 474 & 53 \\
\hline IntI1 & $\begin{array}{l}\text { GGGTCAAGGATCTGGATITCG } \\
\text { ACATGGGTGTAAATCATCGTC }\end{array}$ & 483 & 60 \\
\hline IntI2 & $\begin{array}{l}\text { CACGGATATGCGACAAAAAGGT } \\
\text { GTAGCAAACGAGTGACGAAATG }\end{array}$ & 788 & 60 \\
\hline $\begin{array}{l}5^{\prime}-\mathrm{CS} \\
3^{\prime}-\mathrm{CS}\end{array}$ & $\begin{array}{l}\text { GGCATACAAGCAGCAAGC } \\
\text { AAGCAGACTTGACCTGAT }\end{array}$ & variable & 52 \\
\hline $\begin{array}{l}\text { Ti-F } \\
\text { Ti-B }\end{array}$ & $\begin{array}{l}\text { ACCTIITGTCGCATATCCGTG } \\
\text { CTAACGCTTGAGTTAAGCC }\end{array}$ & variable & 55 \\
\hline
\end{tabular}


against AMP, CIP, co-trimoxazole, PI, SF, and TR. Statistically highly significant $(p<0.01)$ variations in resistance amongst the isolates from organized and unorganized farms were recorded in case of Ax, AMP, cephalexin, CIP, co-trimoxazole, gentamicin, PI, and TR (Table-2).

By double-disk synergy test method, a total of $170 / 258(65.89 \%)$ E. coli isolates were recorded as ESBLs producer, of which $82 / 120(68.33 \%)$ and $88 / 138(63.77 \%)$ were from organized and unorganized farms, respectively.

\section{Genotypic detection of $\boldsymbol{\beta}$-lactamase genes}

A total of $29 / 258(11.24 \%) E$. coli isolates from Mizoram were found to be positive for at least one ESBLs gene. $b l a_{T E M}$ was the most frequently $(25 / 258$; $9.69 \%)$ gene, followed by bla ${ }_{C T X-\mathrm{M}}(13 / 258 ; 5.04 \%)$ and $b l a_{C M Y}(2 / 258 ; 0.78 \%)$. bla $a_{S H V}$ gene could not be detected in any of the isolates under the present study. Altogether, 6/120 (5.00\%), 4/120 (3.33\%), and 2/120 $(1.67 \%)$ E. coli isolates from the organized farms were positive for bla ${ }_{C T X-M}, b l a_{T E M}$, and $b l a_{C M Y}$ genes, respectively. Similarly, 21/138 (15.22\%) and 7/138 (5.07\%) E. coli isolates recovered from the unorganized farms were positive for $b l a_{T E M}$ and $b l a_{C T X-M}$ genes, respectively, and none of them were positive for $b l a_{C M Y}$ and bla $_{S H V}$ genes (Table-3).

\section{Genotypic characterization of non-ESBLs genes}

In Mizoram, of the 258 isolates from both organized and unorganized farms, a total of $83 / 258$ $(32.17 \%)$ E. coli isolates were positive for at least one non-ESBLs genes, of which 57/258 (22.09\%), 9/258 (3.49\%), 66/258 (25.58\%), 78/258 (30.23\%), 21/258 (8.14\%), and 18/258 (6.98\%) E. coli isolates were found to be positive for tetA, tetB, sull, sul2, aadA, and $d$ frla genes, respectively (Table-3). The prevalence of non-ESBLs genes was more in the E. coli isolates from the unorganized farms compared to the isolates from organized farms. tet $B$ and $d$ frIa genes were not found in any E. coli isolates from the organized farms (Table-3).

\section{Detection of antibiotic resistance integrons and gene cassettes}

In the present study, a total of $24 / 258(9.30 \%)$ E. coli isolates were found to be positive for Class 1 integrons (intI1), of which 6/120 (5.00\%) were from organized farms and 18/138 (13.04\%) were from unorganized farms (Table-3).

\section{Discussion}

So far, a very limited study has been conducted on the prevalence of MDR E. coli in pigs under organized and unorganized farming set up in Northeastern region of India except few sporadic reports on ESBLs producing enteric bacteria in man and animals. The present study was conducted to investigate the prevalence of MDR E. coli isolates from pigs of organized and unorganized farms in Mizoram with special emphasis on determination of ESBLs production, determination of ESBLs and non-ESBLs genes, as well as integrons and gene cassettes.

In the present study, a total of $258 \mathrm{E}$. coli were isolated and identified from 98 fecal samples collected from pigs of organized and unorganized farms of Mizoram, India with or without a history of diarrhea. E. coli is a commensal in the intestinal tract of man and animals. The population in the gut may vary depending on the physiological and/or pathological status of the host. A similar or little variable rate of $E$. coli isolation from various animals is reported from India and abroad. Earlier, from the same laboratory, Lalzampuia et al. [11] isolated $102 \mathrm{E}$. coli from 53 fecal samples from pigs in Mizoram. On the other

Table-2: Antibiotic resistance profile of $E$. coli isolated from fecal samples of pig from organized and unorganized farms of Mizoram, India.

\begin{tabular}{lcccc}
\hline Antibiotics & Organized farm $(\mathbf{n = 1 2 0})$ & Unorganized farm $(\mathbf{n = 1 3 8})$ & Total $(\mathbf{n = 1 3 8 )}$ & ND value \\
\hline Amoxicillin & $111(92.50)$ & $100(72.46)$ & $211(81.78)$ & $4.16^{* *}$ \\
Ampicillin & $27(22.50)$ & $61(47.66)$ & $88(35.48)$ & $3.67^{* *}$ \\
Aztreonam & $18(16.36)$ & $31(22.46)$ & $49(19.76)$ & $1.52^{\mathrm{NS}}$ \\
Cephalexin & $144(96.00)$ & $102(73.91)$ & $246(85.42)$ & $4.58^{* *}$ \\
Cefixime & $48(40.00)$ & $38(27.54)$ & $86(33.33)$ & $2.12^{*}$ \\
Cefotaxime & $17(14.17)$ & $24(17.39)$ & $41(15.89)$ & $0.71^{\mathrm{NS}}$ \\
Ceftazidime & $35(29.17)$ & $40(28.99)$ & $75(29.07)$ & $0.03^{\mathrm{NS}}$ \\
Ceftriaxone & $12(10.00)$ & $20(14.49)$ & $32(12.40)$ & $1.09^{\mathrm{NS}}$ \\
Ciprofloxacin & $3(2.50)$ & $18(13.04)$ & $21(8.14)$ & $3.09^{* *}$ \\
Co-trimoxazole & $42(35.00)$ & $89(64.49)$ & $131(50.78)$ & $4.73^{* *}$ \\
Gentamicin & $7(5.83)$ & $24(17.39)$ & $31(12.02)$ & $2.85^{* *}$ \\
Imipenem & $0(0.00)$ & $2(1.45)$ & $2(0.78)$ & $1.32^{\mathrm{NS}}$ \\
Nalidixic acid & $46(38.33)$ & $33(23.91)$ & $79(30.62)$ & $2.51^{*}$ \\
Piperacillin & $32(26.67)$ & $63(45.65)$ & $95(36.82)$ & $3.15^{* *}$ \\
Streptomycin & $8(6.67)$ & $20(14.49)$ & $28(10.85)$ & $2.02^{*}$ \\
Sulfafurazole & $77(64.17)$ & $102(73.91)$ & $179(69.38)$ & $1.69^{\mathrm{NS}}$ \\
Tetracycline & $74(61.67)$ & $96(69.57)$ & $170(65.89)$ & $1.33^{\mathrm{NS}}$ \\
Trimethoprim & $45(37.50)$ & $89(64.49)$ & $134(51.94)$ & $4.33^{* *}$ \\
\hline
\end{tabular}

*Statistically significant $(p<0.05)$ between organized and unorganized farm; **Highly significant $(p<0.01)$ between organized and unorganized farm; NsNot significantly different $(p<0.01)$ between organized and unorganized farm. Figures in parentheses are indicated as percentages. 
hand, Lalruatdiki et al. [15] could recover 867 E. coli from 228 fecal samples from pigs of Meghalaya and Assam. On the other hand, Samanta et al. [16] reported only $76 E$. coli from 200 fecal samples in West Bengal, India. The rate of isolations of E. coli from fecal samples may vary depending on the nature of samples, types of media used, laboratory practices of the researchers, treatment status of the host, and so on. A number of $E$. coli colonies picked up from a particular sample is also variable. It may lead to variation in the frequency of $E$. coli isolates from a particular number of samples. In this study, we have picked up a minimum five suspected colonies randomly from primary culture plate for further confirmation by morphological and biochemical characteristics to avoid false-negative result.

In the present study, 62/258 (24.03\%) E. coli isolates exhibited resistance to antimicrobial agents against the minimum of three classes, hence, MDR. The resistance pattern of E. coli isolates against the third-generation cephalosporins was variable. Moreover, variations were also recorded between the isolates from organized and unorganized farms. NARMS report showed that resistance to CTR ranged from $6.3 \%$ to $13.5 \%$ among $E$. coli isolated from chickens during 2000-2008. In contrast to our result, Sasirekha et al. [17] reported 84\%, 75\%, and $85 \%$ resistance to CTX, CTR, and CAZ, respectively, among the E. coli isolates from pigs. On the other hand, Rosengren et al. [18] reported no resistant isolates against CTR and $<1 \%$ resistance to cefoxitin and ceftiofur. Interestingly, E. coli isolates from unorganized farms exhibited higher resistance against majority of the commonly used antimicrobials in Mizoram. It may be due to overuse of antibiotics through self-medication, introduction of antimicrobial residues through swill feeding or even through environmental contamination, particularly contaminated water [4]. Most of the ESBLs producing organisms were also co-resistant to fluoroquinolones, aminoglycosides, and COT, which corroborates with the earlier findings [14], where the ESBLs producing enteric bacteria were found to be resistant to other groups of antibiotics including aminoglycosides, TE, sulfonamides, TR, and chloramphenicol. Development of co-resistance against other antibiotics along with $\beta$-lactam antibiotics by the ESBLs producing organisms generally appears in the large plasmids, where most of the resistance genes may coexist [1].

In this study, 6/120 (5.00\%), 4/120 (3.33\%), and $2 / 120(1.67 \%) E$. coli isolates from the organized farms were positive for $b l a_{C T X-M}, b l a_{T E M}$, and $b l a_{C M Y}$ genes, respectively. However, on the other hand, 21/138 $(15.22 \%)$ and $7 / 138(5.07 \%) \mathrm{E}$. coli isolates from the unorganized farms were positive for $b a_{T E M}$ and $b l a_{C T X-M}$ genes, respectively. In addition, none of them were positive for $b l a_{C M Y}$ and $b l a_{S H V}$ genes (Table-2), which is in corroboration with the observation of other workers from abroad except one report from the same 
laboratory [11], wherein a small scale study, 7(5.07\%) and $3(2.17 \%) E$. coli isolates from pigs of Mizoram were recorded as positive for $b l a_{C T X-\mathrm{M}-1}$ and $b l a_{T E M}$ gene, respectively, of which $3(2.17 \%)$ isolates were positive for both the genes. Globally, the prevalence of $C T X-M$ producing $E$. coli is varied between $0.8 \%$ in Europe to $25.0 \%$ [19]. The variation of results, in this study, in comparison to the other reports, may be due to the lower expression of $C T X-M$ genes. bla $_{\text {CTX-M }}$ genes spread throughout the community, mostly through the transmission of plasmids, and some studies have also reported that animals may serve as a possible source for the dissemination of ESBLencoding genes to humans [12]. Indeed, from the same laboratory bla $a_{C T X-\mathrm{M}}$ genes in E. coli from human and animals from Mizoram is already published [11,12], which also suggest that the transfer of extended-spectrum cephalosporin resistance between animals and humans frequently occur [4]. In the present study, the TE (tet $A$ and tetB) and sulfonamides (sull and sul2) resistance genes were detected most frequently in unorganized farms. The present findings are in contrast with the earlier findings in Arunachal Pradesh, where non-ESBLs associated genes were more from the isolates from the organized farms [14]. It might be due to more frequent use of such classes of antimicrobials under unorganized farming system in recent years. The presence of tet and sul genes has been reported as a prevailing mechanism for TE and sulfonamide resistance, respectively, in E. coli isolates from pet animals and wild animals. As mentioned in an earlier section that in Mizoram, the pigs under unorganized farms are getting exposed to more antimicrobials compared to its organized counterparts. Class 1 integrons are the most common antibiotic-resistant genes found in the clinical isolates of Gram-negative bacteria [14]. In an earlier, Kar et al. [10] also reported class integrons in clinical isolates of $E$. coli from Odisha, India. Integrons have been identified as a primary source of resistance genes and are claimed to be reservoirs of AMR genes within microbial populations.

\section{Conclusion}

In the present study, MDR E. coli were isolated and identified from the pigs under organized and unorganized farming system in Mizoram, India. E. coli isolates from unorganized farms exhibited significantly higher resistance against the third-generation cephalosporins and AMP. In addition, the same isolates were also exhibited more ESBLs and non-ESBLs AMR genes, which correlate with the phenotypic observations. The presence of more number of MDR E. coli isolates in unorganized farming set up compared to the organized pig farms is a serious indication of misuse or overuse of antimicrobials in this environment.

\section{Authors' Contributions}

RM: Collection of samples, processing for isolation and identification of bacteria, AST, PCR assays.
TKD: Genesis of concept of the work and preparation of the manuscript. PR: Detection of ESBLs genes by PCR assays. PKS: AMR sensitivity assay and data analysis. HK: Sample collection and processing for isolation and identification. IS: Preparation of manuscript and editing. SB: Preparation of manuscript and editing. All authors read and approved the final manuscript.

\section{Acknowledgements}

The authors are thankful to the Dean, College of Veterinary Sciences and Animal Husbandry, Department of Biotechnology (DBT) project on Advanced Animal Disease Diagnosis and Monitoring Consortium (ADMaC) (Grant No. DBT-NER/ LIVS/11/2012) and DBT project on Institutional Biotech Hub (No. BT/B1/12/042/2007) for providing all the facilities to conduct the present work.

\section{Competing Interests}

The authors declare that they have no competing interests.

\section{Publisher's Note}

Veterinary World remains neutral with regard to jurisdictional claims in published institutional affiliation.

\section{References}

1. Mandakini, R., Dutta, T.K., Chingtham, S., Roychoudhury, P., Samanta, I., Joardar, S.N., Pachauau, A.R. and Chandra, R. (2015) ESBL producing Shiga-toxigenic E. coli (STEC) associated with piglet diarrhoea in India. Trop. Anim. Health Prod., 47(2): 377-381.

2. Chellapandi, K., Dutta, T.K., Sharma, I., Mandal, S.D., Senthilkumar, N. and Ralte, L. (2017) Prevalence of multi drug-resistant enteropathogenic and enteroinvasive Escherichia coli isolated from children with and without diarrhea in Northeast Indian population. Ann. Clin. Microbiol. Antimicrob., 16(1): 49-57.

3. Kylla, H., Dutta, T.K., Roychoudhury, P., Subudhi, P.K. and Lalsiamthara, J. (2019) Prevalence and molecular characterization of Salmonella species associated with piglet Diarrhea in North East India. Pol. J. Vet. Sci., 22(4): 793-797.

4. Puii, L.H., Dutta, T.K., Roychoudhury, P., Kylla, H., Chakraborty, S., Mandakini, R., Kawlni, L., Samanta, I., Bandopaddhay, S. and Singh, S.B. (2019) Extendedspectrum $\beta$-lactamase producing Shiga-toxin producing Escherichia coli in Piglets, humans and water sources in North East region of India. Lett. Appl. Microbiol., 69(5): 110-115.

5. Cheng, A.C., Turnidge, J., Collignon, P., Looke, D., Barton, M. and Gottlieb, T. (2012) Control of fluoroquinolone resistance through successful regulation, Australia. Emerg. Infect. Dis., 18(9): 1453-1460.

6. Samanta, I., Bandyopadhayay, S., Dutta, T.K. and Joardar, S.N. (2019) Antimicrobial stewardship in veterinary medicine: In need of urgent implementation. Indian J. Anim. Health, 58(2): 33-38.

7. Lyhs, U., Ikonen, I., Pohjanvirta, T., Raninen, K., Perko-Makela, P. and Pelkonen, S. (2012) Extraintestinal pathogenic Escherichia coli in poultry meat products on the Finnish retail market. Acta. Vet. Scand., 54(64): 64-73.

8. Amado, S.H., Blanco, P., Rico, M.A., Corona, F., Reales-Calderón, J.A., Sánchez, M.B., Martínez, J.L. 
(2016) Multidrug efflux pumps as main players in intrinsic and acquired resistance to antimicrobials. Drug Resist. Updates, 28: 13-27.

9. Mulisa, G., Selassie, L.G., Tilaye, W., Jarso, G., Shiferew, T., Zewdu, A., Abebe, W., Belachew, F. and Sewunet, T. (2016) Prevalence of extended-spectrum $\beta$-lactamase producing enterobacteriaceae: A cross-sectional study at Adama hospital, Adama, Ethiopia. J. Emerg. Infect. Dis., 1: 1-11.

10. Kar, D., Bandyopadhyay, S., Bhattacharyya, D., Mondal, B., Samanta, I., Mahanti, A., Nanda, P.K., Dandapat, P., Das, A.K., Dutta, T.K., Bandyopadhyay, S. and Singh, R.K. (2015) Molecular and phylogenetic characterization of multidrug-resistant extended-spectrum $\beta$-lactamase producing Escherichia coli isolated from poultry and cattle in Odisha, India. Infect. Genet. Evol., 29: 82-90.

11. Lalzampuia, H., Dutta, T.K., Warjri, I. and Chandra, R. (2013) PCR based detection of extended-spectrum $\beta$-lactamases $\left(\right.$ bla $_{\text {CTX-м }}$ and bla $\mathrm{a}_{\mathrm{TEM}}$ ) in Escherichia coli, Salmonella spp. and Klebsiella pneumoniae isolated from pigs in North-Eastern India (Mizoram). Indian J. Microbiol., 53(3): 291-296.

12. Dutta, T.K., Warjri, I., Roychoudhury, P., Lalzampuia, H., Samanta, I., Joardar, S.N., Bandyopadhyay, S. and Chandra, R. (2013)Extended-spectrum $\beta$-lactamase-producing Escherichia coli isolate possessing the Shiga toxin gene (stx1) belonging to the O64 serogroup associated with human disease in India. J. Clin. Microbiol., 51(6): 2008-2009.

13. Clinical and Laboratory Standards Institute. (2018) Performance Standards for Antimicrobial Susceptibility Testing, CLSI Supplement M100. 28 ${ }^{\text {th }}$ ed. Clinical and Laboratory Standards Institute, Wayne, PA, USA.

14. Mandakini, R., Dutta, T.K., Roychoudhury, P.,
Subudhi, P.K., Samanta, I. and Bandyopadhayay, S. (2019) Isolation, identification and molecular characterization of multidrug-resistant Escherichia coli recovered from pigs of Arunachal Pradesh, India. Indian J. Anim. Health, 58(2): 153-168.

15. Lalruatdiki, A., Dutta, T.K., Roychoudhury, P. and Subudhi, P.K. (2018) Extended-spectrum $\beta$-lactamase producing multidrug resistant Escherichia coli, Salmonella and Klebsiella pneumoniae in pig population of Assam and Meghalaya, India. Vet. World, 11(6): 868-873.

16. Samanta, A., Mahanti, A., Chatterjee, S., Joardar, S.N., Bandyopadhyay, S., Sar, T.K., Mandal, G.P., Dutta, T.K. and Samanta, I. (2018) Pig farm environment as a source of $\beta$-lactamase or AmpC-producing Klebsiella pneumoniae and Escherichia coli. Ann. Microbiol., 68(11): 781-791.

17. Sasirekha, B., Manasa, R., Ramya, P. and Sneha, R. (2010) Frequency and antimicrobial sensitivity pattern of extendedspectrum $\beta$-lactamases producing E. coli and Klebsiella pneumoniae Isolated in a Tertiary Care Hospital. Al Ameen J. Med. Sci., 3(4): 265-271.

18. Rosengren, L.B., Waldner, C.L., Reid-Smith, R.J. and Checkley, S.L. (2008) Antimicrobial resistance of fecal Escherichia coli isolated from grow-finish pigs in 20 herds in Alberta and Saskatchewan. Can. J. Vet. Res., 72(2): 160-167.

19. Hussain, A., Shaik, S., Ranjan, A., Nandanwar, N., Tiwari, S.K., Majid, M., Baddam, R., Qureshi, I.A., Semmler, T., Wieler, L.H., Islam, M.A., Chakravortty, D. and Ahmed, N. (2017) Risk of transmission of antimicrobial-resistant Escherichia coli from commercial broiler and free-range retail chicken in India. Front. Microbiol., 8: 2120 . 